\title{
Implementation Pair Work and Storytelling in Teaching Speaking Fluency in Elementary School
}

\author{
Jihan Rizka Febyanti ${ }^{1}$, Dina Merris Maya Sari ${ }^{1{ }^{*}}$ \\ ${ }^{1}$ Department of English Education, STKIP PGRI Sidoarjo, Sidoarjo, Indonesia \\ *merrisdins1@gmail.com
}

Received: July $17^{\text {th }}, 2021$

Revised: January $30^{\text {th }}, 2022$

Accepted: February $04^{\text {th }}, 2022$

\begin{abstract}
Fluency in English makes a great demand for teachers to start teaching English at the elementary school level. This study aims to examine how the application of paired learning and storytelling and their impact on students. The design in this research is using quantitative method. This study contains how students can interact, communicate and learn in class using pairing strategies and storytelling. The subjects of this study were teacher and students of elementary school. Researcher collects data by observing, interviewing, analyzing documents and communicating personally with teachers and students. The results of this study were applied by students filling out the answer sheets first to express their main ideas. Students will work in pairs and retell by storytelling. This will encourage students to speak. It was concluded in this study that students can speak about $110-113$ words in every minute with a pause of about 1-3 seconds.
\end{abstract}

Keywords: pair work; story telling; speaking fluency

\section{INTRODUCTION}

In this era of globalization, English is an important international language and an important competency that must be mastered (Arizona \& Sari, 2021). Young learners are the right age to teach English to students, that age if with a good and appropriate strategy it will produce effective learning and students will be more fluent in English. According to Islamiyah (2021), learning English will be more easily accepted by students when they are at an early age than when students are adults. Based on a study conducted by Makarim (2021) stated that almost all parents of students expect that their children will master English, this will provide encouragement and will provide opportunities for students to learn English at an early age.

In the current industrial 4.0 era, there are several aspects that must be considered in the learning system, namely a more innovative learning system so that it can create competent and skilled graduates in the 21st century. This is implemented in order to encourage economic growth and strong competitiveness (Sari \& Prasetyo, 2021). Thus makes teachers have to be able to find the right strategy for their students. According to Rasyad (2020) learning for 
young learners is still not maximal. Likewise, there are difficulties for teachers to find suitable strategies in learning English.

Although some schools or courses speak English for several years, however, there are some that still have not implemented English to young learners well and effectively. Some teachers still have not applied some TEYL principles to young learners properly.

Storytelling and sharing enable the class to make sense of the world through a range of diverse cultural perspectives (Taranto, 2021). According to (Linse, Nunan , \& David, 2005), storytelling will have a lot of impact on learning English at various ages. Storytelling can build good communication in the classroom. With frequent storytelling in a cool style, children will find it easier to understand and this can add a lot of knowledge to children from an early age. Storytelling will also be very good for the listeners, it can increase their listening value listening

Harmer (2002) states that children are enjoying something new and that way teachers can give something new and learn from a variety of sources. Firdausah (2020) argue that there is a strategy that makes teaching Indonesian language easier, the strategy is learning in pairs or pair work. Working in pairs will make language teaching more efficient, easy to implement and easy to understand.

Frastiwi (2020) states that English is a very important language because it is used as an international language, but there are difficulties when learning
English, especially if it is not taught early on. English itself has four mandatory skills that must be mastered. By mastering these four skills, a person will be said to be proficient in English. The three skills are speaking skill, witting skill, listening skill and reading skill. In order for someone to speak English fluently, one must master or have speaking skills. Speaking skill is a basic skill to learn English.

According to Thornburry (2005), fluent English is the capacity of a student to produce real English without pauses when speaking and no hesitation when speaking. Fluency is a feature that gives a very natural quality of speech, including when students give a slight pause, rhythm, intonation, stress, speech rate, and such original use. exclamations and interruptions. This study aims to examine how the application of paired learning and storytelling and their impact on students.

\section{METHODOLOGY}

This research was a quantitative research. In this type of research, the researcher collected, classified, analyzed, and drew conclusion based on the data analysis without making a generalization. (Creswell., 2009 ) states that a quantitative research is a study to investigate and understand the meaning individuals or groups assume to be a social or a human problem. It is used to find out and know why and how a social phenomenon happens. The final written report of this study consists of introduction, literature and theory, 
methods, results, discussion, and conclusion.

The subjects of this research are the teacher dan students of elementary school. Moreover, words or phrases are the form of data in the quantitative study. The investigation about the implementation and advantages was carried out by needs analysis using observation; interview and document analysis.

\section{RESULTS}

\section{a. The Implementation of Pair work} and Storytelling

In this study, teaching was carried out based on the syllabus and lesson plans. The syllabus itself is used by teachers to assist the course of learning, namely to regulate the learning process and design the teaching and learning process and also the syllabus serves as a guide for teaching and learning materials. And the syllabus itself contains several important elements for the course of learning. The elements are competency standards, basic competencies, indicators, learning objectives, time allocation, learning activities, and the last is assessment.

The syllabus and lesson plans are usually made based on interview data, but the syllabus will usually be further developed into English and Indonesian lesson plans. Data from interviews usually contain the procedures and how to organize to achieve the goals of the basic competencies that have been set. The lesson plans will be developed by the teacher based on the syllabus.
Based on the results of observations, the teacher has applied the teaching and learning process by using a pair strategy and with storytelling material. The implementation itself requires several important stages, namely: opening, core activities, and finally closing. These steps still contain several activities in each step. In the first step of the opening there are steps of exploration, elaboration, and confirmation. In the elaboration step, in this step a teacher will usually act as a facilitator for the students. The teacher will divide the students into pairs and tell stories. The teacher will encourage students to develop their own ideas by distributing answer sheets to them and they will write down their main ideas and ideas with the guidance of the teacher. The teacher will help these students by facilitating their students to work or study cooperatively and collaboratively while studying. In the next step, the teacher will facilitate the students by helping them to present the results of the collaboration between their partners in front of the class.

\section{b. The Impact of Pair Work and Story Telling toward Students' Speaking Fluency}

English lessons are generally only done once a week, with a fairly limited teaching time, the teacher must be able to use the time as effectively as possible. Moreover, with pair work and storytelling, the teacher will give students more opportunities to talk in class. According to the researcher, a student 
can speak about 110 to 130 words per minute. Some of them were found to still use filters when speaking such as "emmm", "eeee", "uh" up to two to four times. However, this is still very reasonable at the elementary school level. That's because they are looking for ideas that are in their minds before they continue to speak. While the indicators of fluency itself include speed (rate of speech), semantic density (filler), and indecision (pause).

After getting the data, the researchers processed the data and obtained the amount of $X$ data of 4409, the number of $Y$ of 1170 , the number of $X 2$ of 403723 , the number of $Y 2$ of 28206 , and the total of $X Y$ of 103174. Then the data were correlated to find the value of $r_{x y}$ by using pearson product moment. Based on the calculation of the product moment, it produces $r_{x y}$ value of 0.96678 .

Table 1. Correlation between Pair Work and Story Telling toward Students' Speaking Fluency

\begin{tabular}{ll}
\hline $\begin{array}{c}r \text { Product } \\
\text { Moment }\end{array}$ & Interpretation \\
\hline
\end{tabular}

\begin{tabular}{ll}
$0,00-0,19$ & Very low/very weak \\
& correlation \\
$0,20-0,39$ & Low/weak correlation \\
$0,40-0,59$ & Medium correlation \\
$0,60-0,79$ & High correlation \\
$0,80-1,00$ & Very high correlation \\
\hline
\end{tabular}

Based on the interpretation of table 1 of the correlation coefficient that the value of $r_{x y}=0.96678$, it is interpreted that between the variables $\mathrm{x}$ and $\mathrm{y}$ has a very high relationship. So it can be concluded that the variables $x$ and $y$ greatly influence each other. Likewise, the one in discussed in this study is storytelling has an effect on students' speaking skills.

With the results of the speaking skills test through oral storytelling, the following is a recapitulation of test scores covering 7 aspects (Table 2)

Table 2. Speaking Test Score

\begin{tabular}{llcccc}
\hline \multicolumn{1}{c}{ Aspect } & \multicolumn{5}{c}{ Score } \\
\cline { 2 - 6 } & $\mathbf{5}$ & $\mathbf{4}$ & $\mathbf{3}$ & $\mathbf{2}$ & $\mathbf{1}$ \\
\hline Spelling & 7 & 16 & 12 & 13 & 2 \\
Vocabulary & 8 & 17 & 20 & 17 & 8 \\
Structure & 4 & 18 & 14 & 11 & 3 \\
Content & 8 & 14 & 22 & 5 & 1 \\
Fluency & 6 & 27 & 7 & 8 & 2 \\
Style & 8 & 13 & 19 & 8 & 2 \\
Intonation & 3 & 19 & 13 & 9 & 6 \\
\hline
\end{tabular}

Meanwhile, the value of the questionnaire is presented in figure 1. Based on the acquisition of a questionnaire that uses 35 statements to 30 respondents, resulting in data acquisition of the number of those who chose Strongly Agree (SA) as many as $40 \%$, who chose Agree (A) is $55 \%$, those who choose Disagree (D) are $5 \%$, and those who choose Strongly Disagree (SD) are $0 \%$. 


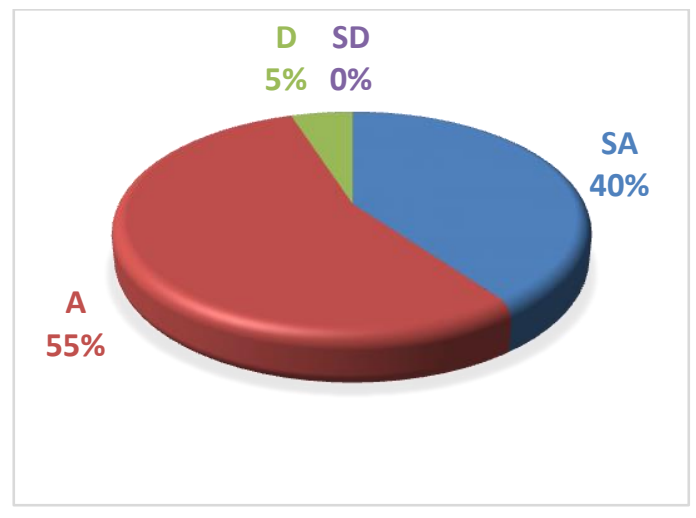

Figure 1. Speaking Fluency

\section{DISCUSSION}

Based on this research, it can be concluded that pair work learning and storytelling in the classroom are believed to provide effectiveness in the teaching and learning process at the elementary school level, more precisely in the process of learning to speak English to students. Because reading or telling a story with a story that is easy to understand and funny will make students master it faster and develop the speaking process of students' (Arizona \& Sari, 2021). Pair work and storytelling will be full of responsibility and learn to work with their partners. Coupled with listening to stories that are captured funny, it will make it easier for them to catch and know how to pronounce correctly. By listening to easy-tounderstand and funny stories they will also know how to pronounce it wrong and how to pronounce it right. This will be very effective as they learn to acquire their mother tongue.

Sari (2021) states that storytelling will really helpful to fluency in English. The growth of children's language skills and their total growth are intertwined, but they are raised separately (Freeman, 2004). Therefore, to get good results by using dialogue teaching strategies, teachers must have a time plan before giving lessons to students starting from preparation, application, and closing.

Motivating is also useful to increase students" enthusiasm. In line with (Rasyad \& Sari, 2020), he argues that the motivation of the teacher in the classroom affects the learning of English. Keeping students motivated and interested are two important factors. Motivation and interest are crucial in supporting student success with challenging, informative activities that support success and which help the student learn complex skills. When students are motivated and interested in the material they are learning, they make greater connections between topics, elaborations with learning material and can recall information better (2020).

The overall implementation of pair work and storytelling influences the students' speaking fluency. As stated by (AWP \& Sari, 2020) that in foreign language learning fluency includes speaking with a good but not necessarily perfect command of intonation, vocabulary, and grammar. In this study, the students are stated as fluent in speaking after they have assessed by using Linse's indicators. Most students are able to talk in a coherent way and have appropriate things to say. They speak in normal speed around $110-130$ words per minute. According to (Makarim $\&$ Sari, 2021) the average speech rate of 
an elementary school is 130 wpm, which is considerably slower than the natural speed of native speakers (about 160 to 190 wpm). When they search the correct manner to say their words, they may use fillers such as "uhm', „emm' and have a silent pause or silent period in $1-3$ seconds. The concept of "think time', defined as a distinct period of uninterrupted silence by the teacher and all students so that they both can complete appropriately information processing tasks, feelings, oral responses, and actions. Moreover, periods of silence lasted more than 1,5 seconds in typical classrooms.

After observing the students" speaking activities in the classroom, it can be concluded that most students are able to speak English fluently when the teacher implements pair work and storytelling. They can speak in everyday conversation and classroom discussions generally fluent, with occasional lapses while they search for the correct manner of expressions. Moreover, students are able to produce spoken language to communicate ideas with ease but not necessarily perfect command of intonation, vocabulary, and grammar.

\section{CONCLUSION}

From the $r_{x y}$ calculation above that between storytelling and students' speaking skills it is known that the correlation coefficient index is 0.96678 and after consulting the interpretation table, it turns out that the number. There is a very high correlation on the effect, namely between variable $X$ and variable $Y$, because $r$ is between $(0.80-0.100)$.

Pair work and storytelling are well implemented in the fifth grade speaking class. It makes all students have opportunities to speak up for a limited time and brings positive effects toward the students themselves. In order to introduce English to young learners, they need to get exposed to the language much. Being exposed to the English language teaching instruction will accommodate the language use. Additionally, the main goal of International Primary School enables the students to use English as their communication language through various learning activities and learning materials. From the implementation of the pair work and storytelling to teach speaking, it can be drawn important point that it gives impact to students" speaking fluency. It makes students speak and interact actively with their peers. Besides, the students intention to speak is increased when the teacher implements pair work and storytelling. It can make students be fluent because they have opportunities to produce more spoken.

\section{REFERENCES}

Arizona, M. S., \& Sari, D. M. (2021). Paraphrasing Strategy in EFL Learners' Reading Skill. Magister Scientiae, 49(1), 66`-76.

AWP, W., \& Sari, D. M. (2020). Students' Attitude in Reading Classroom. 
Jurnal Ilmiah Wahana Pendidikan, 6(4), 849-854.

Creswell, J. W. (2012). Educational research: Planning, conducting, and evaluating quantitative and qualitative research (4th ed.). Boston: Pearson.

Firdausah, A., \& Sari, D. M. (2020). Project Based Learning on EFL Students' in Essay writing. Jurnal IImiah Wahana Pendidikan, 6(4), 841-848.

Frastiwi, S., \& Sari, D. M. (2020). Teaching Essay Writing to The ELT Students. Jurnal IImiah Wahana Pendidikan, 6(4), 835-840.

Harmer, J. (2002). The Practice of English Language Teaching (3rd ed). The Practice of English Language Teaching (3rd ed)., 38.

Islamiah, S. F., \& Sari, D. M. (2021). Using Outlining Strategy in Essay Writing for ELT Students. Jurnal Basis-Bahasa dan Sastra Inggris, 8(1), 141-152.

Linse, C., Nunan , \& David. (2005). Practical English Language Teaching: PELT Young Learners. . New York: McGraw-Hill.

Makarim, H. N., \& Sari, D. M. (2021). Google Classroom in The English Language Teaching Learning during Pandemic Covid-19. Jurnal Pendidikan Bahasa, 10(2), 141150.

Murcia, \& Marianne , C. (2001). Teaching English as a Second or Foreign language, Third Edition. Boston: Thompson Learning Inc.
Rasyad, M. F., \& Sari, D. M. (2020). Students' Difficulties of Essay Writing on Virtual Learning. Jurnal Ilmiah Wahana Pendidikan, 6(4), 867-871.

Sari, D. M. (2016). The use of skimming and scanning techniques to improve reading comprehension achievement. Edukasi, 2(1),59-68.

Sari, D. M. (2019). An error analysis on students' translation text. Eralingua: Jurnal Pendidikan Bahasa Asing dan Sastra , 3(2), 65-74.

Sari, D. M. (2019). An overview of genre based approach in EFL writting class. JournE, 1(1), 31-40.

Sari, D. M. (2020). Contextual redefinition : A teaching strategy for enchacing beginner level of reading achievement. Journal of English Educational Study, 110118.

Sari, D. M., \& Prasetyo, Y. (2021). Project-Based-Learning on Critical Reading Course to Enhance Critical Thinking Skills. Studies in English Language and Educational Study, 8(2), 442-456.

Sari, D. M., \& Wardhani, A. K. (2020). Critical thingking as learning and innovation skill in the 21st century. Journal of English and Language Pedagogy, 3(2), 11-21.

Sary, \& Fetty , P. (2006). Teacher's Strategies in Teaching English as a Foreign Language to Primary School Students: $A$ Thesis. . Bandung: Universitas Pendidikan Indonesia. 
Taranto, E. (2021). "Telling Mathematics": Storytelling and Counting in Pre-Elementary School. Journal of Teaching and Learning In Elementary Education, $3(1)$,
$1-21$. http://dx.doi.org/10.33578/jtlee.v $3 \mathrm{i} 1.7820$

Thornburry, S. (2005). How To Teach Speaking. New York: Longman. 